Rogers, H. J. (1954). J. gen. Microbiol. 10, 209-220.

\title{
The Rate of Formation of Hyaluronidase, Coagulase and Total Extracellular Protein by Strains of Staphylo- coccus aureus
}

\author{
BY H. J. ROGERS
}

\author{
National Institute for Medical Research, Mill Hill, London, N.W. 7
}

\begin{abstract}
SUMMARY: Hyaluronidase is formed as a constitutive enzyme by Staphylococcus aureus growing in either broth or casein hydrolysate media. The lag in the appearance of hyaluronidase activity after inoculation of a culture is longer than the lag in growth. A change in the rate of formation of hyaluronidase therefore occurs after exponential growth has been established. Activity per unit volume of culture supernatant increases exponentially faster after this initial lag than the mass of bacteria; it stops increasing abruptly sooner than growth. Coagulase appears, after inoculation, without lag additional to that in growth but increases at a slower rate than growth until it too ceases to increase before growth stops. Evidence is presented to show that changes in enzymic activity of the culture represent enzyme formation and not secondary changes in formed protein or secretion phenomena. The changes in rate of enzyme formation are connected with processes controlling enzymic specificity of the proteins rather than with general processes involved in manufacturing extracellular protein.
\end{abstract}

It was shown some years ago that whereas Clostridium welchii and streptococci produce more hyaluronidase when casein hydrolysate or peptone media are supplemented by hyaluronate, staphylococcal enzyme formation is unaffected by the addition of hyaluronate (Rogers, 1945). Thus hyaluronidase appears to be an adaptive or induced enzyme in the former species but a constitutive one in the latter. Further analysis of the course of production of hyaluronidase by staphylococci has been undertaken in order to investigate the mechanism of constitutive enzyme formation.

Little information exists on the course of enzyme formation, particularly of extracellular enzymes, under circumstances which preclude adaptive response to substrates in the growth medium; also, in most of the cultures studied the organisms have ceased to multiply exponentially. Attention in the present work has been concentrated on changes in the rate of hyaluronidase, coagulase, and protein formation which occur during the logarithmic phase of growth. A steady state can never be established in an ordinary culture, but changes in enzyme formation which occur during a period of exponential growth must be due to some change in the culture which alters enzyme formation without affecting growth. For example, the cells may accumulate some substance necessary for hyaluronidase or coagulase formation, or inhibitors may be removed from the medium. In order to be able to correlate the measured hyaluronidase activities with the formation of the enzyme an attempt has been made to exclude activation of any pro-hyaluronidase or inactivation of formed enzyme. The amount of cell-bound hyaluronidase has also been examined because, from the results obtained, it seemed possible that the cells might be accumulating hyaluronidase in the early stages of growth and releasing it later. 
The course of coagulase formation has been chosen as a comparative study to that of hyaluronidase, partly because results obtained by Davies (1951) suggest that coagulase may be formed very rapidly under some circumstances once the cells have started to multiply, whereas the present work has shown that in early growth hyaluronidase formation lags.

\section{METHODS}

Cultural conditions and strains of organism. Two strains of Staphylococcus aureus were used for the detailed work reported here (i.e. 524 and Newman); both were isolated by Dr C. H. Lack. A description of the isolation of variants from 524 has been published elsewhere (Rogers, 1953). Similar results, not given here in detail, have been obtained with two other strains (isolated by Dr R. E. O. Williams) which produced sufficient hyaluronidase and coagulase to allow measurement of both in the same culture. Unless otherwise stated, the organisms were grown in lightly plugged Ehrlenmeyer flasks containing 0.2 of their volume of medium, shaken 88 times per min. with a horizontal traverse of $8 \mathrm{~cm}$. in an incubator maintained at $35 \pm 0.5^{\circ}$. The media were warmed to $35^{\circ}$ on the morning of the day of the experiment and inoculated with $0.15 \mathrm{ml} . / 100 \mathrm{ml}$. of an $18 \mathrm{hr}$. culture of the particular strain to be investigated, grown in Hedley Wright broth buffered with $2.5 \%(\mathrm{w} / \mathrm{v})$ sodium glycerophosphate and containing $\mathbf{0} \cdot 25 \%(\mathrm{w} / \mathrm{v})$ glucose. Two media have been used: (a) The above-mentioned buffered Hedley Wright broth; $(b)$ the supplemented casein hydrolysate medium previously described as medium B (Rogers, 1945). Growth took place exponentially during a considerable proportion of the total growth in both media.

The cultures were usually sampled at half-hourly intervals by withdrawing the required volumes aseptically from the flasks and delivering them into 'Iusterlite' centrifuge tubes immersed in a mixture of ice and water. Samples from these tubes were then taken into ice-cold diluting fluid for the measurement of bacterial growth, and the tubes were centrifuged for $15 \mathrm{~min}$. or longer at about 4000 r.p.m. in a centrifuge kept at $0-4^{\circ}$. The supernatants were then removed, a drop of toluene added and they were stored at $0-4^{\circ}$ or at $-2^{\circ}$ for not longer than 24-48 $\mathrm{hr}$.

Estimation of bacterial growth. The mass of bacterial growth was estimated by the opacity of suitable dilutions of the cultures using a Spekker photoelectric colorimeter and an Ilford neutral grey filter H508. The size and grouping of staphylococci change during growth and it was, therefore, necessary to make sure that any change in the relationship between opacity, dry weight and total bacterial nitrogen (used as an approximate estimate of bacterial protein) was not sufficient to interfere with the interpretation of the results. Five samples were taken from a culture of Staph. aureus (strain 524) growing in the broth medium, at 4, 6 and $20 \mathrm{hr}$. after inoculation. Sample 1 was diluted and the opacity of a range of dilutions was measured; duplicate samples 2 and 3 were centrifuged, the cells were washed twice with saline and their total nitrogen content was estimated by a conventional micro-Kjeldahl technique; duplicate samples 4 and 5 were centrifuged, the cells were washed 
twice with distilled water and transferred to tared weighing bottles and dried to constant weight at $105^{\circ}$.

The nitrogen content as a percentage of the cell dry weight was approximately constant $(11 \cdot 9-12 \cdot 5 \%)$ for the period over which samples were examined. Fig. 1 shows that for the first two samples the relationship between opacity and bacterial nitrogen was the same within the limits of the methods; but for

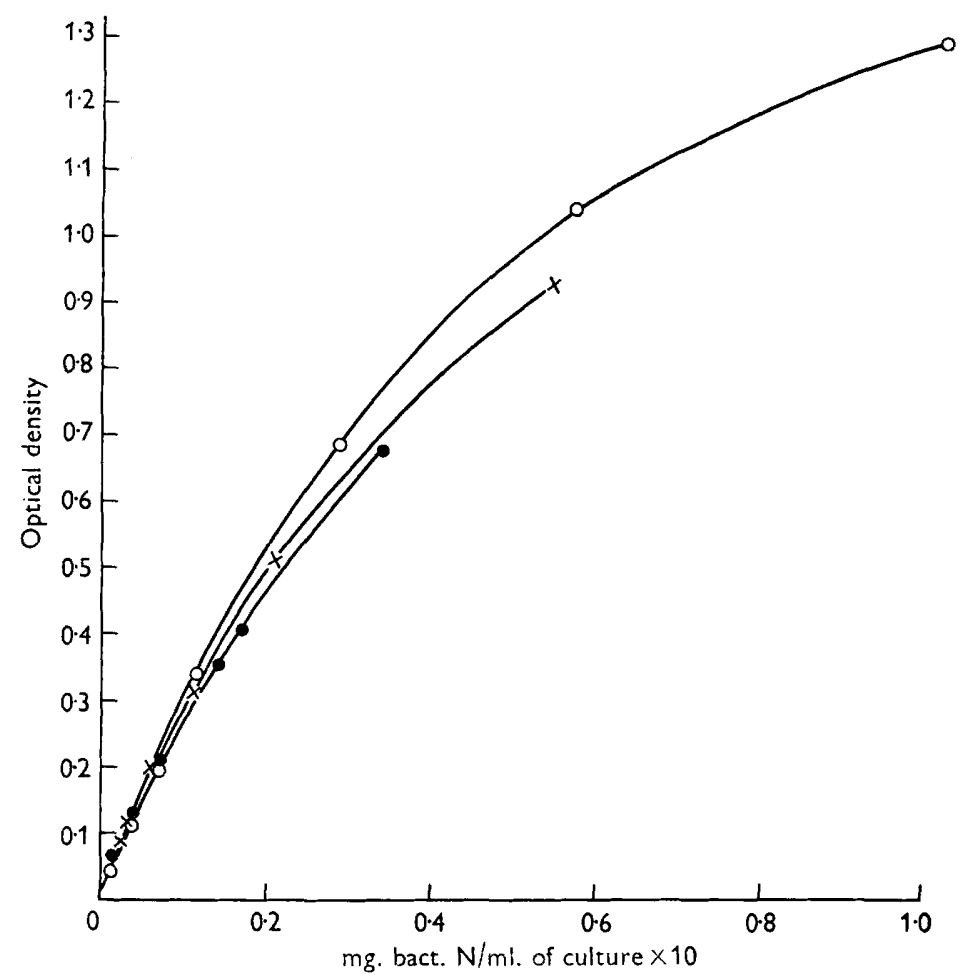

Fig. 1. The relationship between optical opacity and bacterial $\mathbf{N}$ (for samples taken at different times from a growing culture of Staphylococcus aureus strain 524). - $-4 \mathrm{hr}$. culture; $-x-, 6 \mathrm{hr}$. culture; $-O-, 24 \mathrm{hr}$. culture.

the sample collected $20 \mathrm{hr}$. after inoculation the relationship was different. As will be shown later, the most important part of the work was concerned with the period up to 7 or $8 \mathrm{hr}$. after inoculation. It was, therefore, thought to be satisfactory to use only opacity as a measure of the mass of bacterial growth, and hence of bacterial protein. When overnight cultures were examined, the appropriate curve for the relationship between bacterial $\mathbf{N}$ and opacity was used. Results are expressed as $\mathrm{mg}$. bacterial $\mathrm{N} / \mathrm{ml}$. culture.

Estimation of hyaluronidase. The Tolksdorf, McCready, McCullagh \& Schwenk (1949) modification of the turbidity reduction method was used. Gelatin at a concentration of $0.2 \%$ was present in all the tubes including the standards containing only buffered substrate. The addition of gelatin to the standard tubes as well as the tests is of importance since it has considerable 
effect upon the turbidity given by the hyaluronate when mixed with the acidified serum reagent. A final concentration of $10^{-4} \mathrm{M}$-sodium pyrophosphate was also present throughout the tests as an additional guard against heavy metal inactivation of the enzyme (Meyer \& Rapport, 1951). Crucial values were always rechecked using three different concentrations of the culture supernatants. 'The term hyaluronidase must in this paper be taken to mean the enzyme, formed by staphylococci, which breaks down hyaluronate sufficiently to be estimated by the above technique. Results are expressed as turbidity reducing units (T.R.U.) per ml.

Estimation of coagulase. The technique which is commonly employed for estimating the potency of coagulase by finding the dilution of the supernatant which just fails to coagulate either suitable plasma, or a combination of fibrinogen and suitable 'activator', was not sufficiently precise for the purposes of the present investigation. Therefore, coagulase was measured by the time taken by dilutions of the culture supernatants to clot fresh, whole, pooled human plasma under standard conditions. Clotting time was estimated by dropping ballotini glass balls, no. 12 (Chance Bros. Ltd., Birmingham), into a tube containing the plasma-culture supernatant mixture. The tubes were incubated at $37 \pm 0.5^{\circ}$ in an ordinary glass-sided flocculation bath with a strong light on the side opposite the operator and focused on the tubes. When clotting occurred the brilliantly refractile balls could be seen to stop abruptly in their downward course. A plot of the logarithm of the time taken to clot the plasma against the logarithm of the volume of supernatant used, gave a satisfactory straight line, provided the clotting time was between 1 and $10 \mathrm{~min}$. This double logarithmic relationship was first observed for thrombin clotting by Fischer (1935). An arbitrary unit, the 'clot', was defined as the volume of supernatant which, when adjusted to $0.5 \mathrm{ml}$. with normal physiological saline, would clot $1.0 \mathrm{ml}$. of human plasma in $240 \mathrm{sec}$. at $37^{\circ}$ in a tube $0.5 \mathrm{~cm}$. in diameter, agitated by constant tapping.

Estimation of total extracellular protein. The amounts of protein present in supernatants from cultures examined up to 5 or $6 \mathrm{hr}$. after inoculation were too small to allow the use of conventional methods such as the estimation of trichloroacetic acid insoluble nitrogen. Recourse was, therefore, had to a method designed by Lowry, Rosebrough, Farr \& Randall (1951) which combines the biuret and Folin-Ciocalteu phenol estimations using trichloroacetic acid precipitates. This method has been found to be very reproduceable providing great care is taken in centrifuging and handling the very small precipitates obtained. A disadvantage of the method is that the same weights of different proteins give different depths of colour. Therefore, if any considerable change takes place in the types of soluble protein formed during growth of the organisms, the comparative results may be inaccurate. The greatest difference, however, demonstrated by Lowry et al. (1951), that between trypsin and gelatin, was a threefold difference in colour. It is thought to be unlikely that the interpretation of the results will be seriously affected since the formation of a high proportion of protein of very low tyrosine content is unlikely. 


\section{RESULTS}

The course of appearance of extracellular hyaluronidase and coagulase

'The potency of hyaluronidase was measured in the supernatants from cultures of the unselected Staphylococcus aureus (strain 524) growing in the buffered broth medium. Sampling was started soon after inoculation and continued over most of the growth period. Fig. 2 shows the result of one such

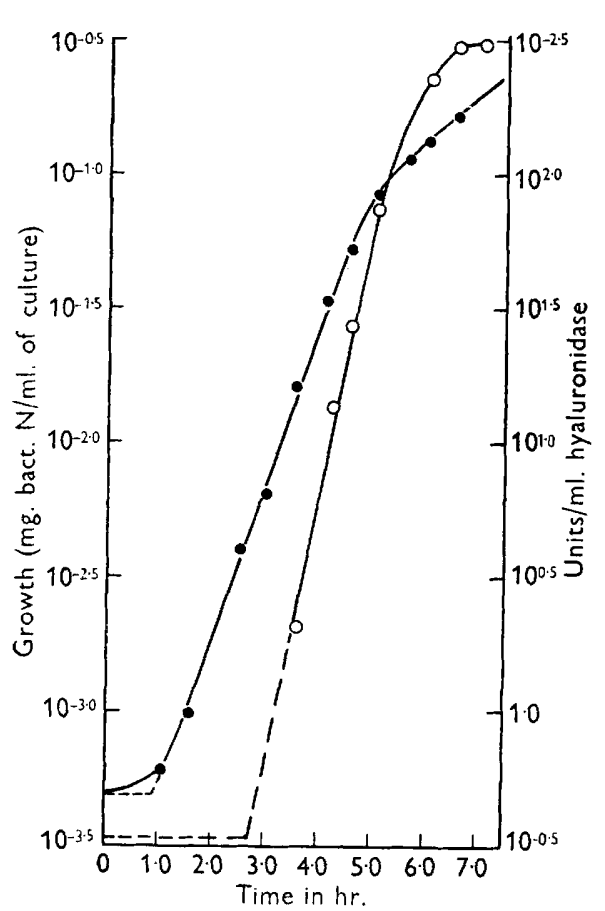

Fig. 2

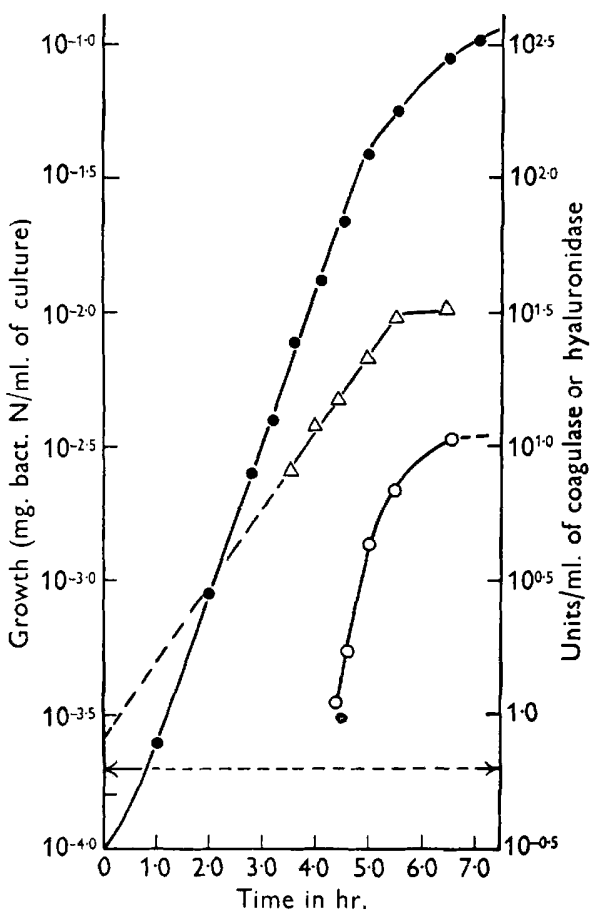

Fig. 3

Fig. 2. The course of growth and hyaluronidase appearance plotted as logarithmic functions relative to the age of the culture, using Staph. aureus (strain 524). - - , bacterial growth as mg. bact. $\mathrm{N} / \mathrm{ml}$. of culture; $-\mathrm{O}$, hyaluronidase as T.R.v./ml. of culture supernatant.

Fig. 3. The course of growth, coagulase and hyaluronidase formation plotted as logarithmic functions relative to time in cultures of Staph. aureus (strain Newman). - --, bacterial growth as $\mathrm{mg}$. bact. $\mathrm{N} / \mathrm{ml}$. of culture; $-\bigcirc-$, hyaluronidase as T.R.U./ml. of culture supernatant; $-\triangle-$, coagulase as clots $/ \mathrm{ml}$. of culture supernatant. The horizontal broken line indicates the inoculum level of coagulase.

experiment, where the logarithms of both the mass of bacterial nitrogen and the enzyme potency in the culture superantant are plotted against time. By extrapolating both of the lines to meet the lines drawn parallel to the time axis through the initial values for the inoculum, two so-called lag periods are obtained. The initial values were calculated from the known dilutions of the culture used for inoculation. Whereas the lag period for growth was only about 1.0 hr., that for the appearance of enzyme was $2 \cdot 8 \mathrm{hr}$. Enzyme forma- 
tion thus continues to accelerate after the rate of multiplication of bacterial mass has become constant. The lag period in enzyme formation was rather variable but was always more than twice that for bacterial growth. There seemed to be no correlation between the two. No more enzyme was formed after about $7 \mathrm{hr}$., whereas growth continued until the mass of bacteria had increased twofold or threefold after $18 \mathrm{hr}$. incubation. The same type of relationship was obtained using casein hydrolysate medium $\mathbf{B}$, except that the whole pattern of enzyme formation was more variable.

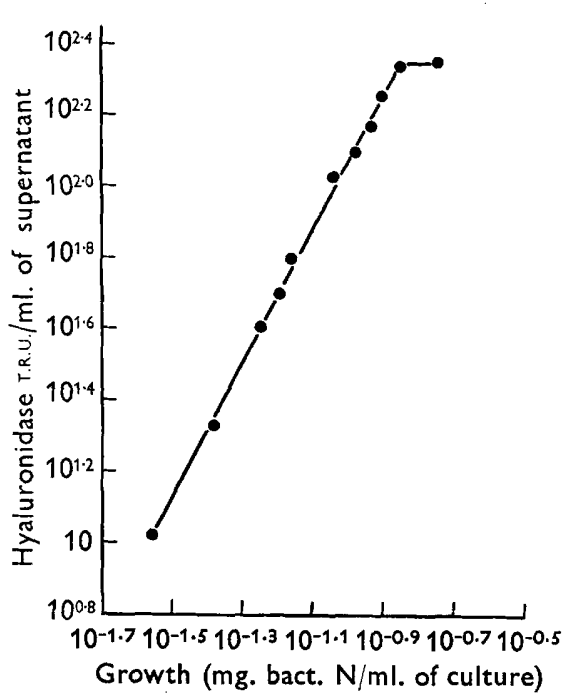

Fig. 4

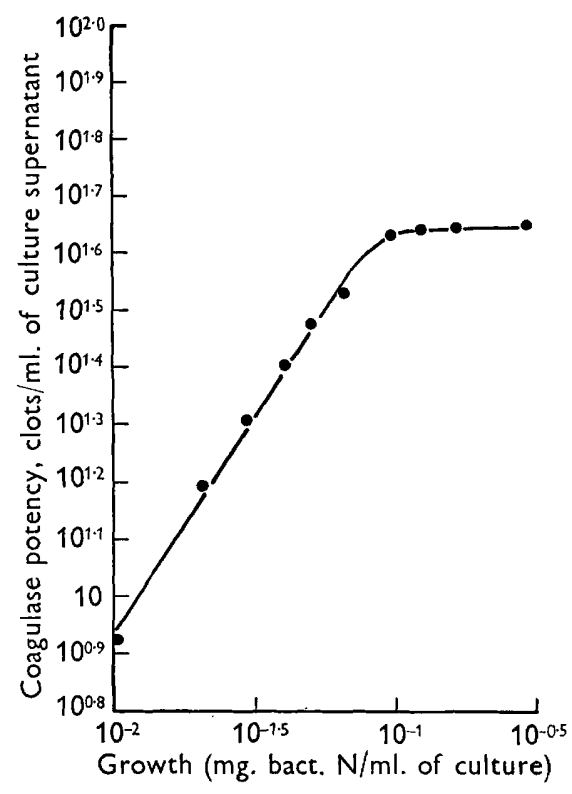

Fig. 5

Fig. 4. The course of appearance of hyaluronidase relative to the amount of bacterial growth plotted as a double logarithmic function. The results represent the mean of five experiments using cultures derived from a single pair of cells of strain 524.

Fig. 5. The double logarithmic function for the appearance of coagulase in cultures of Staph. aureus strain Newman. The results represent the mean of two experiments.

When coagulase production by strain 'Newman' was examined a different relationship was obtained. Fig. 3 shows that coagulase appeared rapidly immediately growth began and again ceased before the bacterial mass had stopped increasing. On the same figure are plotted the results for the weak hyaluronidase formed by this strain. The latter enzyme again shows the same type of curve as that obtained for strain $\mathbf{5 2 4}$.

Measurements of the slopes of the logarithmic plots of hyaluronidase and coagulase potency against time showed that the principal difference between the behaviour of the two entities was that after the initial lag hyaluronidase appeared faster than bacterial growth, whereas coagulase appeared more slowly but without initial lag. If this were true, an approximate straightline relationship should exist for the formation of both when the logarithm of growth is plotted against the logarithm of potency. Figs. 4 and 5 show the 
results of such plots. The straight line for the production of hyaluronidase is drawn through the results from five different experiments using cultures derived from a single pair of cocci isolated by micro-manipulation (Rogers, 1953). The results for coagulase formation also fall on a straight line but the slope of the line is much less steep.

Thus hyaluronidase appears in the culture more rapidly and coagulase less rapidly than bacterial protein, but there is a lag in the appearance of hyaluronidase during which growth is proceeding at maximum rate. A possible explanation of this lag in hyaluronidase formation could be the progressive activation or inactivation of the enzyme. If, for example, hyaluronidase were unstable in the medium when present in low concentration but were stabilized by an increase in concentration, one might expect the enzymic activity of the culture to display the type of phenomenon described. Alternatively, an inactive soluble pro-enzyme might be formed during early stages of growth and be progressively activated as the bacterial mass increased. To test these two possibilities two types of experiment were done. (1) Samples of supernatant taken from the late production phase of the organisms (strain 524) were diluted in fresh medium so as to give the potency of the hyaluronidase expected if enzyme formation had been in direct relation to growth at the time when growth was equivalent to $0.02 \mathrm{mg}$. bacterial $\mathrm{N} / \mathrm{ml}$. These dilutions were incubated for $4 \mathrm{hr}$. at $37^{\circ}$ and assayed. The greatest degree of inactivation recorded from such experiments was $13 \%$. Such a loss would be far too small to account for the discrepancy between enzyme actually found (i.e. c. 4-5 T.R.U.) and that to be expected (90 T.R.U./ml.). (2) Samples from the early growth phase of the cultures were mixed with those from the middle and end of the enzyme production phase. These mixtures were then incubated at $37^{\circ}$ for $90 \mathrm{~min}$., cooled and assayed in the usual way. If inactive pro-enzyme is produced early in the culture and later activated, it should be possible to demonstrate that the mixture has more than the theoretical enzyme potency after incubation. No evidence for activation of early samples by later ones could, however, be obtained. This, of course, does not exclude the possibility of the activation of some pro-enzyme-like substance by the activities of the cells themselves.

\section{Cell associated hyaluronidase and coagulase}

The lag period in the formation of hyaluronidase would also be consistent with an accumulation of the enzyme inside the cells followed by release. To test this possibility samples were taken at various stages of growth of the cultures, centrifuged, the cells were washed rapidly once with $1 / 10$ the volume of ice cold $0.1 \mathrm{M}$-phosphate buffer at $\mathrm{pH} \mathrm{7.0}$ and then resuspended in $1.0 \mathrm{ml}$. amounts of the same buffer. At first the cells in the suspension were broken by shaking with ballotini glass-balls, no. 12, at 50 cyc./min. (Curran \& Evans, 1942). It was subsequently found that the enzyme present in the cells is released on storage of the suspensions in buffer overnight at $0-4^{\circ}$. The latter method was used to estimate the amount of cell-bound enzyme. It is subject to two errors; first, about $10-15 \%$ of the enzyme remains associated with the 
cells and secondly, an increase in the total potency of the enzyme in the suspension occurs during storage. This increase is very irregular and may be due to traces of medium constituents carried with the cells and not removed during the single washing with phosphate buffer. Washing, however, cannot be made more thorough since a considerable proportion of the enzyme known to be present when cells were immediately broken, was removed. The enzymic activity associated with the cells was small and the errors involved were not likely to affect interpretation of the relation between cell-bound and cell-free enzyme.

It was found that no enzyme could be detected in cell suspensions prepared from $18 \mathrm{hr}$. cultures; thus the enzymic content of the cells was less than 0.5 T.R.U./mg. bacterial $N$ when these were inoculated into fresh medium. Table 2 shows that as cultures were incubated cell associated enzyme appeared and increased per unit mass of cells until the culture filtrate had reached about a third of the potency it would eventually attain. Thereafter there was a decrease in units of cell-associated hyaluronidase. In order to account for the deficiency in the enzymic potency of the culture at, say, the stage represented by the first sample examined for content of cell-associated enzyme, the cells would have had to contribute $c .100$ units $/ \mathrm{ml}$.; in fact, they could have contributed only $0.8 \mathrm{unit} / \mathrm{ml}$., or $0.8 \%$ of the deficiency. Several experiments of this type were conducted, and suitable controls were included to make sure that enzyme was not destroyed during the process of extraction from the cells. It was concluded that secretion as such does not play a major role in determining the lag in the production of hyaluronidase.

Table 1. The relation between the potency of hyaluronidase associated with the cells and that in solution in growing cultures of Staphylococcus aureus (strain 524)

\begin{tabular}{|c|c|c|c|c|}
\hline \multirow[b]{2}{*}{$\begin{array}{l}\text { Age of } \\
\text { culture } \\
\text { (hr.) }\end{array}$} & \multirow{2}{*}{$\begin{array}{c}\text { Mass of } \\
\text { growth } \\
\text { (mg. bact. } \\
\text { N/ml. } \times 10)\end{array}$} & \multicolumn{2}{|c|}{ Cell associated enzyme } & \multirow{2}{*}{$\begin{array}{c}\text { Cell free } \\
\text { enzyme } \\
\text { (T.R.U./ml. } \\
\text { culture) }\end{array}$} \\
\hline & & $\begin{array}{l}\text { T.R.U./mg. } \\
\text { bact. } \mathbf{N}\end{array}$ & $\begin{array}{c}\text { T.R.U./ml. } \\
\text { culture }\end{array}$ & \\
\hline $4 \cdot 0$ & $0 \cdot 23$ & $33 \cdot 7$ & 0.78 & 4 \\
\hline 4.75 & 0.68 & $53 \cdot 8$ & $\mathbf{3 \cdot 6}$ & 65 \\
\hline $5 \cdot 2$ & $1 \cdot 08$ & $61 \cdot 0$ & $6 \cdot 6$ & 116 \\
\hline $6 \cdot 0$ & $\mathbf{1} \cdot \mathbf{3 7}$ & $\mathbf{2 4} \cdot 0$ & $\mathbf{3 \cdot 2}$ & 265 \\
\hline 6.8 & $1 \cdot 80$ & 3.8 & 0.68 & 355 \\
\hline $18 \cdot 0$ & $5 \cdot 4$ & $<0.5$ & $<\mathbf{1} \cdot \mathbf{0}$ & 330 \\
\hline
\end{tabular}

Indications were obtained of an approximately constant amount of coagulase associated with the cells of strain 'Newman' throughout growth. Owing to the low potency of this cell-associated coagulase, however, relative to that in the culture supernatant, observations could not be made sufficiently quantitative to be sure.

\section{The production of extracellular protein}

It appears from the above results that the formation of hyaluronidase first accelerates and then remains faster than growth, whilst at least one other active substance, coagulase, is formed at a uniformly slower rate than either hyaluronidase or cell dry weight. In order to assess the degree of specificity of these 
results it is of importance to know the course of production of total extracellular protein. It is possible, for example, that the formation of either hyaluronidase or coagulase is reflecting total protein secretion by the organisms. If so, the course of production of this enzyme presumably would be controlled by factors which also affect the manufacture of a number of other cell proteins. For example, some of the processes involved in the early stages of constructing polypeptide chains might limit the rate of synthesis of several proteins not directly connected with the economy of the cell, but would not necessarily control the enzymic specificity of these proteins.

These experiments were conducted by the same techniques using strain 524 as those already described but in all the experiments medium $B$ had to be used. The amount of trichloroacetic acid precipitable material present in the Hedley Wright medium (A) was far too great to allow the estimation of the very small amounts of protein secreted by the organism. It has, however, been pointed out that the course of enzyme production conforms to the same pattern when the organisms are growing in the casein hydrolysate medium. Two of the variants previously described (Rogers, 1953) were used for this work; one produced very little, the other very potent hyaluronidase.

Table 2. The formation of hyaluronidase and total extracellular protein by cultures of Staphylococcus aureus (strain 524) growing in casein hydrolysate medium (Medium B)

( $I=$ less active variant; $I I=$ more active variant. $)$

\begin{tabular}{|c|c|c|c|c|c|c|c|c|c|c|c|}
\hline \multirow{2}{*}{\multicolumn{2}{|c|}{$\begin{array}{l}\text { Time } \\
\text { hr. min. }\end{array}$}} & \multicolumn{2}{|c|}{$\begin{array}{c}\text { Growth (G) } \\
(\mathrm{mg} . \text { Bact. } \mathrm{N} / \mathrm{ml} . \times 10)\end{array}$} & \multicolumn{2}{|c|}{$\begin{array}{c}\text { Hyalu- } \\
\text { ronidase (H) } \\
\text { (T.R.U./ml.) }\end{array}$} & \multicolumn{2}{|c|}{$\begin{array}{c}\text { Protein (P) } \\
(\mu \mathrm{g} \cdot / \mathrm{ml} .)\end{array}$} & \multicolumn{2}{|c|}{$\begin{array}{l}\text { Ratio: } \\
\text { H/G }\end{array}$} & \multicolumn{2}{|c|}{$\begin{array}{l}\text { Ratio: } \\
\text { P/G }\end{array}$} \\
\hline & & I & II & I & II & I & II & I & II & I & II \\
\hline 0 & 0 & 0.002 & 0.004 & - & - & - & - & - & - & - & $\ldots$ \\
\hline 1 & 0 & 0.003 & 0.005 & - & - & - & - & - & - & - & - \\
\hline 2 & 0 & $0 \cdot 006$ & 0.012 & - & - & - & - & - & - & - & - \\
\hline 4 & 0 & 0.04 & - & - & - & - & - & - & - & - & - \\
\hline 5 & 0 & $0 \cdot 168$ & $0 \cdot 190$ & - & - & $\ldots$ & - & - & - & - & - \\
\hline & 20 & $0 \cdot 294$ & 0.218 & $<0.5$ & $<0.5$ & - & - & - & - & - & - \\
\hline 5 & 50 & $0 \cdot 350$ & 0.427 & $<0.5$ & $2 \cdot 6$ & - & $7 \cdot 0$ & - & $6 \cdot 1$ & - & 16 \\
\hline 6 & 20 & $0 \cdot 650$ & $0 \cdot 661$ & $2 \cdot 1$ & $7 \cdot 2$ & 8 & 11 & $3 \cdot 2$ & 11 & 12 & 17 \\
\hline 6 & 50 & $1 \cdot 16$ & 1.03 & $7 \cdot 7$ & 37 & 17 & 29 & $6 \cdot 5$ & 36 & 15 & 28 \\
\hline 7 & 20 & $1 \cdot 60$ & 1.55 & 17 & 63 & 29 & 37 & 11 & 41 & 18 & 24 \\
\hline 7 & 50 & $2 \cdot 10$ & $2 \cdot 19$ & 24 & 95 & 40 & 63 & 11 & 44 & 19 & 29 \\
\hline & 20 & $2 \cdot 27$ & $\mathbf{2 \cdot 3 4}$ & 33 & 105 & 59 & 79 & 14 & 45 & $26 \cdot 0$ & 34 \\
\hline 9 & 0 & - & $2 \cdot 60$ & - & 134 & - & 92 & - & 51 & - & $\mathbf{3 4}$ \\
\hline 24 & 0 & $4 \cdot 80$ & $4 \cdot 82$ & $22 \cdot 3$ & 132 & 163 & 346 & $4 \cdot 6$ & 27 & $34 \cdot 0$ & 71 \\
\hline
\end{tabular}

Table 2 shows the results obtained. It will be seen that the course of trichloroacetic acid precipitable protein formation is not identical with that of the hyaluronidase over the range of growth during which enzyme is most actively secreted; the production of protein is more nearly proportional to the mass of growth. During the measured active phase of hyaluronidase formation in the experiment recorded in Table 2 , the ratios of enzyme potency/growth increase by factors of 3.5 and $\mathbf{7 \cdot 4}$ for the two variants, whereas during this time the 
ratios of extracellular protein/growth increase by factors of only $\mathbf{1} \cdot \mathbf{6}$ and $\mathbf{1} \cdot \mathbf{7}$. Greater variation in the hyaluronidase ratios could, of course, be obtained if sampling were started earlier. In another experiment, for example, the hyaluronidase ratios for the same two variants increased $9 \cdot 8$ and $11 \cdot 7$ times but the protein ratios increased only 1.3 and 1.5 times. Later, when the growth rate was greatly reduced and enzyme formation had ceased, protein continued to appear. So far this latter phenomenon has not been sufficiently investigated to distinguish between cell proteins arising from autolysis of the cells and proteins truly secreted. That the protein which appears earlier in growth is unlikely to arise by cell breakdown is indicated by the absence or low concentration of nucleic acid in the supernatant. A $70 \mathrm{ml}$. sample of supernatant obtained when growth was equivalent to about $0.2 \mathrm{mg}$. bacterial $\mathrm{N} / \mathrm{ml}$. was mixed with $35 \mathrm{ml}$. of $20 \%(\mathrm{w} / \mathrm{v})$ trichloroacetic acid, allowed to remain at room temperature for $60 \mathrm{~min}$., and the precipitate was removed by centrifuging. This precipitate was then washed twice with $15 \mathrm{ml} .10 \% \mathrm{CCl}_{3} \cdot \mathrm{COOH}$ and extracted with a hot 1:1 mixture of ethanol and ether $(20 \mathrm{ml}$.$) to$ remove any phospholipids present. It was then dried, dissolved in $\mathbf{2 . 0} \mathrm{ml}$. of $3 \% \mathrm{NaOH}$, and its total phosphate content was estimated to be less than $2 \mu \mathrm{g} . / \mathrm{ml}$. There was $1.01 \mathrm{mg}$. protein $/ \mathrm{ml}$. in the precipitate as shown by the Lowry et al. (1951) method, and consequently the nucleic acid/protein ratio was less than 1/50. From this it seems probable that very little nucleic acid had been released into the culture fluid with the protein as would be likely if the protein arose from cell autolysis. No nucleases could be demonstrated in the culture supernatant, which might otherwise have accounted for the disappearance of liberated nucleic acid.

The amount of soluble trichloroacetic acid precipitable protein in the cultures of the less active hyaluronidase-forming variant is always slightly less than in those of the more active one. The difference, however, is not sufficient to suggest that defective protein secretion alone accounts for the variation in final enzyme potency. Unfortunately the difference between the final amounts of hyaluronidase formed by the two variants is less with casein hydrolysate media than it is with broth media.

Thus the course of formation of total extracellular proteins reflects the formation of neither coagulase nor hyaluronidase with any precision. It is much more nearly related to the growth rate than to either of the activities measured and a possible reason for this will be discussed later. It seems that the rate of formation of hyaluronidase and coagulase can be regarded as in some degree the result of specific causes.

\section{DISCUSSION}

The rate of increase of hyaluronidase in growing cultures of Staph. aureus first accelerates and then remains steady at a rate faster than that of growth. The growth rate itself has become constant within experimental error considerably before the early change in rate of enzyme formation is complete and remains so for a considerable time afterwards. The results are similar whether broth or acid hydrolysed casein media are used. There is no substrate or partially 
degraded substrate in the latter and the results are not therefore due to direct adaptive response. Moreover, the organisms form no more hyaluronidase when hyaluronate is added (Rogers, 1945). It is difficult to compare the picture with earlier studies on the rate of formation of other enzymes (cf. Gale, 1943) because many of the amino acid decarboxylases and deaminases which have been intensively studied require coenzymes and are adaptive enzymes (Gale, 1946). As Gale (1951) has pointed out, variations in enzyme formation which occur with changing $\mathrm{pH}$ of the culture may be related to alterations in the degree of ionization of the amino acids present in the growth medium. Also in almost all this earlier work the cultures examined had grown past the exponential phase.

It is probable that the phase during which hyaluronidase is formed faster than the organisms are growing could only last for a short time. If the period of growth at constant rate is prolonged (Novick \& Szilard, 1950; Monod, 1950; Jeener, 1953; Anderson, 1953), the rate of enzyme formation and growth must eventually become equal, otherwise gross unbalance in the metabolism of the cell would result. For example, if extracellular protein were formed as rapidly as hyaluronidase, the cells would be secreting at least $13 \%$ of their protein by the end of exponential growth instead of the observed value of only $3 \%$. That limited unbalance in the cell can be tolerated during growth at constant rate is in conformity with Jenner's (1953) observation that the ratio of ribonucleic acid to protein in Polytomella caeca cells continues to change for a time after a constant growth rate has been established. Eventually this ratio becomes constant at a characteristic value.

It is not yet known with certainty whether the early change in the cultures of staphylococci which causes hyaluronidase formation to accelerate is due to the accumulation of some essential substance or to the removal of an inhibitor. Results to be published later, however, strongly favour the first explanation, and it seems probable that this substance remains closely associated with the cells. The formal similarity between the course of production of constitutive hyaluronidase and the induced formation of enzymes may be noted.

The cessation of both hyaluronidase and coagulase formation which occurs during the period of slow growth following the exponential phase contrasts with the earlier studies (Gale, 1943) in which enzyme formation ceases only with growth. It seems unlikely that the cessation observed in the present work is a dynamic balance between formation and destruction since prolonged incubation after growth has ceased leads only to a very slow loss of hyaluronidase or coagulase.

\section{REFERENCES}

ANDERson, P. A. (1953). Automatic recording of the growth rates of continuously cultured micro-organisms. J. gen. Physiol. 36, 733.

Curran, H. R. \& Evans, F. R. (1942). The killing of bacterial spores in fluids by agitation with small inert particles. J. Bact. 43, 125.

Davies, G. E. (1951). Factors influencing the in vitro production of staphylococcal coagulase. J. gen. Microbiol. 5, 687 .

Fischer, A. (1935). Gerinnungszeit und Konzentration des Gerinnungsstoffes. Biochem. Z. 278, 320. 
GaLE, E. F. (1943). Factors influencing the enzymic activities of bacteria. Bact. Rev. 7, 139.

Gale, E. F. (1946). The bacterial amino acid decarboxylases. Advanc. Enzymol. 6, 1. GaLe, E. F. (1951). In Bacterial Physiology, p. 436, by Werkman, G. H. \& Wilson, P. Academic Press Inc.

JEENER, B. (1953). Ribonucleic acid and protein synthesis in continuous cultures of Polytomella caeca. Arch. Biochem. 43, 831.

Lowry, O. H., Rosebrough, N. J., Farr, A. Z. \& Randali, R. J. (1951). Protein measurement with the Folin phenol reagent. J. biol. Chem. 193, 265.

Meyer, K. \& RAPport, M. M. (1951). The inhibition of testicular hyaluronidase by heavy metals. J. biol. Chem. 188, 485.

Monod, J. (1950). The technique, theory and application of continuous culture. Ann. Inst. Pasteur, 79, 390.

Novick, A. \& SzIlard, L. (1950). Experiments with the chemostat on spontaneous mutations of bacteria. Proc. nat. Acad. Sci., Wash. 36, 708.

Rogers, H. J. (1945). Conditions controlling the production of hyaluronidase by micro-organisms grown in simplified media. Biochem. J. 39, 435.

Rogers, H. J. (1953). Variant populations within a hyaluronidase producing culture of Staphylococcus aureus. J. Path. Bact. 66, 545.

Tolksdorff, S., McCready, M. H., McCullagh, D. R. \& Schwenk, E. (1949). The turbidimetric assay of hyaluronidase. J. Lab. clin. Med. 34, 74.

(Received 14 August 1953) 